\title{
Discurso \\ em Resenha
}




\section{Advertência dos editores}

Para marcar seus 50 anos de existência, a revista Discurso dá início à publicação de uma nova seção, "Discurso em Resenha", dedicada à divulgação de livros e outras produçóes de filosofia, artes, literatura e ciências humanas, especializadas ou que se situem no cruzamento entre diferentes áreas de produção de conhecimento e atividade cultural. Não que resenhas não tenham feito parte da longa história desta publicação. Essa seção, porém, é animada por uma intenção algo diferente, incitar a leitura e a reflexão, sem que se pretenda dar às obras e objetos abordados um tratamento exaustivo. O esforço aqui é a apresentação, propositalmente sucinta, de impressóes de leitura, chamamentos e toda sorte de abordagens que se mostrem convenientes e interessantes. Os livros e outras produçóes que ocupam a seção não seguem à risca o fluxo do mercado editorial, embora sejam de lavra recente. Tentaremos também, a cada nova ediçáo, convidar à leitura de livros esgotados, e que, por razóes as mais diversas, continuam a merecer, passado algum tempo, a atenção das leitoras e leitores. Tal seção, intitulada "Fora da estante", é como que um apelo à releitura e, se possível, à reedição de tais obras. 
Johann W. Goethe.

Divã ocidento-oriental. Daniel Martineschen (trad.). São Paulo: Estação Liberdade, 2020.

Heinrich Heine dizia que os Versos do Divã ocidento-oriental "são tão leves, tão afortunados, tâo respiráveis, táo etéreos, que nos perguntamos como seria possível equipará-los em língua alemã." É a essa obra, que nos dizeres de outro grande poeta alemão é incomparável, que o leitor lusófono ganha acesso. Escrito já em anos de maturidade, aliás o tema da velhice perpassa os versos dessa obra, o Divã, advindo do persa diwan, que significa "coletânea" ou "ciclo", segundo a indicaçấo de Marcus Mazzari na orelha do volume, é o primeiro, e único, livro de poemas publicado com essa caracterização de obra fechada em seu próprio ciclo. Obras como as Elegias Romanas, apareceram sob essa forma apenas em revistas ou em organizaçôes de poesias completas do autor quando este ainda vivia. Esse ciclo de poemas de Goethe, que em nada lembra outras visōes, digamos, ficcionais, do oriente, como alguns contos de Voltaire ou as célebres Cartas Persas de Montesquieu, traz a intençấo do poeta de "ser visto como viajante, que merece ser elogiado se conseguir assimilar com afinco os modos específicos do estrangeiro, se conseguir se apropriar dos usos da língua, se souber compartilhar modos de pensar e aceitar costumes" (P. 28I). Goethe se inspirou nos versos de $\mathrm{Hafez}$, um poeta persa do século XIV. O autor de Fausto parece querer indicar os intentos de sua obra ao presentar os versos desse poeta: "deles flui uma vivacidade temperada, mas sempre crescente, modestamente feliz e inteligente, que contempla de longe os mistérios da divindade" (p. 313) . Inspirado por sua poesia, o alemão parece ter querido emular as tópicas e algumas formas poéticas caras ao oriente. Na ediçấo brasileira também foram traduzidos os textos em prosa que acompanham o ciclo de poemas. O que esses textos nos mostram é a tentativa de se alcançar um simulacro de uma poesia em muito distante de seu leitor sem que se deixe de estabelecer certo grau de originalidade. Os esforços de se apresentar aos leitores o caráter de um tipo de escrita, a oriental, mais precisamente a persa, faz com que as linhas que acompanham o volume de poemas sirvam de baliza de leitura e de tábua de intençôes de seu autor: "A arte poética persa, porém, bem como tudo que se assemelha a ela, nunca será recebida pelo ocidental em toda sua pureza e com toda facilidade, um fato que devemos ter claro em nossas mentes se não quisermos ser repentinamente perturbados em nosso deleite”. A intenção aqui é a de fornecer mediaçôes tanto à original poesia persa de Saadi, Hafez, Jami entre outros, quanto à apropriaçáo que o poeta faz dela. É no duplo viés do "ocidento-oriental" que devemos entender os poemas que compóem os doze livros desse Divã. O autor náo se esquece de ser o que é, homem ocidental, alemão. É no sentido de enriquecer a poesia alemã que seus olhos se lançam ao oriente: "Permitamos pois, que nos nossos compósitos escritos, ao lado das formas ocidentais e nórdicas, apareçam também as orientais e meridionais", escreve ele na máxima I095. O livro, que se faz embebido das formas orientais, ainda que se trate de um livro alemão, se apresenta como um mediador entre esses dois mundos: "Se a amada não te está rente, / como o Oriente do Ocidente, no ermo o peito está corrente. / Para todos os amantes / Bagdá não está distante." (p. 177). Essa distância, que só pelo amor se vence, é o que parece movimentar os versos desse livro. Não se trata de explorar a estranheza que surge do confronto desses dois universos poéticos, mas de apresentar temas que seriam caros não só às duas culturas, mas à poesia em geral. As tópicas que percorrem os versos em nada são estranhas a nós, a velhice, o amor, a embriaguez, a relaçấo com o divino, as visóes da natureza entre outras, nos trazem a um universo poético que parece visar não só ao mundo exótico e característico de um certo oriente, mas também a própria afinidade com qualquer leitor e seus respectivos movimentos anímicos. Para quem sente, não fica longe 
este oriente. Diante das obras orientais, para além da parábola e da fábula, também nos cabe o exercício de "nos educar a respeito da nossa condição europeia e como avaliá-la". A alteridade se apresenta como elemento constituinte do próprio conhecimento de si.

A tradução de Daniel Martineschen, repleta de soluçóes elegantíssimas, nos repropóe mais uma vez essa unidade na dualidade, é ao leitor brasileiro que a tradução se dirige, e nisso consegue nos inserir nos jogos poéticos do grande poeta alemáo e na sua emulaçáo do oriente. A opçáo de traduzir os textos em prosa que Goethe anexou ao ciclo de poemas é muito feliz, pois algumas passagens ali inseridas nos trazem não só indicaçōes acerca do livro em questão, mas também alguns recursos e modos de composiçáo da própria poética de Goethe como um todo. Enfim, convidamos os leitores a percorrerem esse ciclo poético que, para além de ser composto por um alemáo do século XIX, em torno de um oriente que se fez florescer em versos no século XIV, ainda traz em suas linhas muitos movimentos que nos dizem respeito. Para não mais que exemplificar esse aspecto, apresento alguns versos do "Livro do mau humor", que em na nossa condiçáo de brasileiros em 2020, não deixam de nos dizer respeito: "Como os tolos limitados / sempre querem agredir / e os meia-gente, retardados, / gostam de nos oprimir, // Declarei-me livre já, / dos tolos e dos sabidos: / aqueles querem se matar, / estes, são comedidos." (p. 99).

Johann W. Goethe.

\section{A metamorfose das plantas.} Fábio Mascarenhas Nolasco (trad.). São Paulo: Edipro: 2019.

Devemos celebrar o fato de $A$ metamorfose das plantas ganhar mais uma versão em nossa língua. A já notória e quase canônica tradução de Maria Filomena Molder, publicada pela Imprensa Nacional - Casa da Moeda, em Portugal, há muito se encontra para o leitor brasileiro, pelos mais diversos motivos, inacessível, ou melhor, não a podemos encontrar fora das bibliotecas especializadas e cópias xerográficas. Como acreditamos que, em se tratando de obras clássicas, ganham todos com uma nova tradução, é com alegria que recebemos a possibilidade de o leitor brasileiro entrar em contato com essa obra de Goethe táo fundamental. Ela se apresenta como peça chave para que possamos entender seus estudos acerca das formas vivas, ou seja, sua morfologia. $\mathrm{O}$ volume traduzido pelo professor Fábio Nolasco acompanha a tendência das ediçôes canônicas de trazer junto ao ensaio material que o próprio Goethe anexou ao opúsculo dos anos I790. Para além dos textos usuais e já consagrados por diversas ediçôes da obra, a edição brasileira traz ainda como apêndice um fundamental texto do corpus morfológico de Goethe, o ensaio "O experimento como mediador entre objeto e sujeito". Náo vamos aqui comparar as duas traduçóes que partem de premissas, motivaçóes e escolhas que em muito as diferenciam, mas vamos acompanhar o esforço do tradutor em acompanhar o modo com que o poeta alemão transmitiu suas ideias. A metamorfose das plantas, falo do próprio ensaio, é uma obra que tem como meta a própria singeleza. Antes de empreender sua célebre jornada em solo italiano, Goethe queria se dedicar ao grandioso, a ponto de pretender trabalhar em um Romance acerca do universo, do qual possuímos apenas alguns dos seus fragmentos iniciais, como o célebre estudo "Sobre o Granito". Ao retornar à sua pátria, o poeta passou por uma transformação. Em solo italiano passou a valorizar de tal modo o mundo natural, que chegou a comparar o seu estudo com a geometria, que de tão cara a Platão, dizia-se que ele não admitiria em sua academia um ignorante no assunto, Goethe, por sua vez, ao final de sua Viagem à Itália escreveu: "se eu fosse fundar a minha [Academia] eu não aceitaria ninguém que não tivesse se dedicado seria e ativamente ao estudo da natureza" ( Viagem à Itália, ediçáo da Deutsche Klassiker Verlag, p. 443). O texto que agora ganha sua versão brasileira é como um primeiro fruto 
desse novo direcionamento do olhar. Como podemos ver narrado no texto que compóe o volume que agora vem à luz, "O autor compartilha a história de seus estudos botânicos", é na viagem de retorno à Alemanha que o poeta ordenava "em reflexáo silenciosa uma exposiçáo satisfatória dessas minhas visões, a qual escrevi logo depois de meu retorno e fiz imprimir." (p.84). Tendo o leitor diante de si essa gama de referências o que se vê no corpo do ensaio mesmo, pode até parecer frustrante, o que explicaria a "recepção fria, quase inamistosa" (p. 3I) que o texto teve em sua primeira impressão. Ao se deparar com os I23 parágrafos do texto o desavisado leitor pode não perceber que essa simplicidade e circunscrição oculta muitos movimentos fascinantes. É na busca por uma singeleza, ou ainda, por uma simplicidade - quer já na própria forma do ensaio, quer nos seus objetos de estudo - , que a força desse opúsculo se faz resplandecer. Passagens como a acerca das leis de transmutaçáo, "segundo as quais a natureza produz uma parte por meio da outra e apresenta as mais distintas figuras mediante a modificação de um único órgão" (p.35), escondem um complexo de proposiçōes que se condensam numa prosa que se pretende breve e coesa. O que se busca é o caminho mais simples. E isso se dá não por mera redução dos interesses, mas por um movimento na direção de um esforço de contração descritiva que ocasiona uma simplicidade intencional da prosa de Goethe diante dos grandes movimentos da natureza e do mundo. O caminho do texto se faz de modo a exercer uma heurística da simplicidade, como Goethe mesmo nos afirma, "Desviaremos nossa atenção daquela [...] metamorfose, que é efetuada de modo contingente, exteriormente, particularmente por insetos, já que ela nos aparta do caminho simples que temos que seguir". Náo estamos diante de uma restriçáo metodológica a um círculo mais restrito, mas da busca da percepçáo da multiplicidade do caso singular, da intensidade do que se apresenta em sua simplicidade. O problema do autor será entender o significado dessas açôes mais simples da natureza como ligadas ao seu todo, a forças e mutações que se dão no mais simples elemento do reino dos vegetais, a planta anual, bem como em todo ser vivente. A linguagem e a própria configuração do ensaio parecem ser análogas à singeleza das observaçóes de Goethe, que escondem muitos aspectos centrais das ciências da natureza, a tradução brasileira dá conta dessa sutileza linguística e nos enriquece com farto aparato de notas. Portanto, celebremos esta traduçáo para o português, brasileiríssima, de $A$ metamorfose das plantas.

\section{Pierre Hadot.}

\section{Não se esqueça de viver - Goethe e a tradição dos exercícios espirituais.}

\section{Lara Christina de Malimpensa (trad.). São Paulo: É realizações,} 2019.

Pierre Hadot, conhecido por obras como O véu de Ísis, Plotino ou a simplicidade do olhar entre outras, cuja contribuição à historiografia das ideias é inquestionável, trouxe ao leitor um livro que parece ser gerido no decorrer de suas muitas décadas de leitura de autores antigos. A presença de Goethe em uma passagem comovente de seu $O$ que é a filosofia antiga, onde o filósofo francês colocava o filósofo antigo como privilegiado por viver "em relaçôes mais ou menos estreitas com um grupo de filósofos, ou, pelo menos, recebia de uma tradição filosófica suas regras de vida" e se perguntava "Agora, não há mais escolas, não há mais dogmas. O filósofo está só. Como encontrará seu caminho?” A resposta nos dá um pouco o tom do livro que pretendemos apresentar aqui: "Ele o encontrará como muitos outros encontraram antes dele, como Montaigne, ou Goethe, ou Nietzsche, que também estavam sós e escolheram como modelos $[\ldots]$ os modos de vida da filosofia antiga" (pp. 388-389). É exatamente nessa chave que o imperativo "não se esqueça de viver" que dá ao livro seu título surge em 
sua clara relação com a vida e a filosofia antigas, bem como profissáo de fé do ofício de vida e poético de Goethe. A obra que ganha agora a sua edição brasileira passa longe de ser um comentário a um determinado ponto da obra de Goethe, mas parece tratar exatamente dessa apropriaçáo da antiguidade e a tópica da vida no todo do corpus goethiano. Não se trata, também, de uma obra que use da figura de Goethe como pretexto para arrolar caracterizaçóes caras aos estudos de filosofia antiga. Diante daquele que o autor declara que "foi sempre um de meus autores favoritos", Hadot parece buscar uma conciliação indicada pelo próprio Goethe entre o mote $\mathrm{Me}$ mento vivere (em oposição ao Memento mori "dos cristãos, dos platônicos e dos românticos" P.io) e a tradiçấo, de certa forma infundida por Winckelmann, de uma antiguidade saudável e plena. Não sem problematizar essa visáo que se teve da antiguidade, a obra nos apresenta a peculiar apropriaçáo dos antigos empreendida pelo alemão. Nessa retomada germânica os gregos e a antiguidade passam a ser elementos fundadores para uma "regra de vida" do poeta, a de se concentrar no instante. É nessa caracterização que a relação de Goethe com o passado remoto da Grécia pode ser entendida como não sendo nostálgica. Ela também não se vê amparada por uma ânsia de que o futuro venha a sanar aquilo tudo que perdemos em relação ao mundo antigo, essa retomada da "saúde do momento" seria para Goethe o que corresponderia a "uma libertação diante do passado e do futuro e a uma disposiçáo de acolhimento, de aceitação, de consentimento diante do ser-no-mundo, vivida no instante" (p.5I). Essa espécie de simbologia do instante, tâo cara à ciência natural de Goethe, se vê amparada por uma gama de exercícios antigos e, na erudiçáo de Hadot, encontra amparo no Imperador Marco Aurélio que embebido da filosofia estoica declarava que a felicidade poderia ser alcançada "se deixas atrás de ti todo passado, se entregas o futuro à providência e se dispóes do presente segundo a piedade e a justiça" (p.5I). Distendidas as metáforas e símbolos desse instante (Augenblick) é para o olhar do alto que o filósofo francês nos leva, no capítulo onde o duplo viés da obra se apresenta de modo inconteste, tratase de apresentar Goethe e ao mesmo tempo fincar as referências antigas que nos serviriam de baliza a tal apresentação. O filósofo nos apresenta aqui os relatos de viagens cósmicas e voos da imaginaçấo advindos de fontes antigas, medievais e modernas. Mas é na antiguidade que vê matizes que dariam a essa tópica as cores com que Goethe as pintou. Retomando passagens como a descrição de Apolônio de Rodes da ascensão de Jasão ao monte Díndino, ou quando o mesmo autor descreve o voo de Eros na direção da terra, entre outros trechos mais conhecidos da antiguidade, chegamos a Linceu, o timoneiro dos argonautas, que nos atos III e V da segunda parte de Fausto ganha seu papel de sentinela, devido a seus olhos (Augen) de lince. Seja diante da beleza de Helena no segundo ato, ou diante da beleza do mundo no quinto ato, é o próprio ver que se manifesta nessa personagem. A afirmaçáo do momento prolífero, segundo Hadot, se apresenta numa sucessão de visões da beleza da torre de Fausto e até mesmo quando, da construção elevada, Linceu observa o incêndio da casinha de Baucis e Filemon, uma das mais terríveis passagens da Tragédia. $\mathrm{O}$ ver do alto, afinal, com a argúcia de um sentinela, se vê defrontado com algo terrível, mas segundo a tópica da simbologia do instante, ainda assim o que se vê são os tons belos de vermelho púrpura que emanam da queima das tílias. O observador diante do terrível - algo que retomaria a tradiçăo antiga, como em Icaromenipo ou o Homem acima das montanhas de Luciano, onde lemos "Não é apenas para meu deleite / que estou em lugar táo elevado / que terror atroz / do fundo das trevas me ameaça?" (p. 85) - não fere uma representaçáo do mundo antigo que geraria a concepçáo goethiana do instante, mas a repropóe, pois eles vivem o instante e segundo a natureza que "é bela em todas as suas manifestaçôes, mas ignora o bem e o 
mal" (p. 86). O sim à vida e à natureza, representado pelo instante deve dar espaço ao terrível, ainda que não permaneça nele, instantes de beleza virão. Na visão de Hadot, em meio aos autores da antiguidade encontramos aspectos para que entendamos Goethe, o autor moderno (ainda que à maneira dos antigos!). Goethe e antiguidade passa a ser duas esferas de referências que, ainda que irreconciliáveis, se complementam e fazem com que náo nos esqueçamos a vida. $\mathrm{E}$ nos lembra $\mathrm{o}$ autor deste livro que para Goethe desfrutar da vida era "encontrar a alegria na existência de si, no que existe de maravilhoso na atividade do corpo e do espírito." (p.I7I) E nessa comunháo com a felicidade retomamos a antiguidade, como foi dito por Amor na XIV Elegia do manuscrito de Erótica Romana (ou XIII na primeira impressão, já sob o nome Elegias): "Eu, o mestre, eternamente jovem sou e aos jovens amo /. Não aja de modo táo precoce! Acorda! Me entendas plenamente! / $\mathrm{O}$ antigo era novo quando aqueles felizes viviam, / Vivas tu em felicidade, e então viverás os tempos antigos em si." (Gedichte 1756-I799, Deutsche Klassiker Verlag, p. 419)

\section{Marcus Vinicius Mazzari. A dupla noite das tílias. História e natureza no Fausto de Goethe. São Paulo: Editora 34, 2019.}

Marcus Mazzari, a quem devemos a excelente edição brasileira de Fausto (edição que se vê amparada com uma fortuna crítica que a coloca ao lado das boas ediçóes alemás, como a de Albrecht Schöne), nos apresenta nesse livro uma leitura do mesmo Fausto que não petrifica a sua leitura. Em $A$ dupla noite das tílias... a obra não é submetida a uma espécie de exame in vitro da letra morta de uma obra canônica, clássica, coisa que mais tende a afastar do que a atrair leitores. O livro de Mazzari nos apresenta os movimentos de recepção bem como análise de passagens, principalmente da segunda parte da tragédia ou do que se convencionou chamar de Fausto II, que nos remeteriam a um estudo in vivo, no qual a palavra ganha vida e atuação. A obra de Goethe nesse $A$ dupla noite das tílias se faz projetar de modo semelhante ao que, segundo Goethe, seria a missão de um grande mestre que "despertando a existência de bons discípulos, ramificam sua atividade até o infinito" (Esboços para um retrato de Winckelmann). É diante da possibilidade dada pelo próprio Fausto de uma ramificaçáo ao infinito que o livro se apresenta como único. Aqui desempenha fundamental papel aquilo que Mazzari chama de Estética de recep̧ăo, onde se centra fogo "menos às fontes ou à estrutura da obra enfocada, ou ainda às eventuais intençóes de seu autor, do que ao papel desempenhado pelo seu leitor no processo de ativação exegética do texto literário." (p. 20). Essa escolha, que é mais do que mero artifício acadêmico, é responsável por nos apresentar essa obra, um clássico par excellence, de modo vivo e cambiante e nos coloca em movimento, seguindo os exemplos dados tanto pela obra quanto por sua recepção. Isso não significa que a leitura esteja submetida ou ainda talhada por teorias, análises ou sistemas, como acontece muitas vezes em estudos que sufocam uma obra literária com toda sorte de sistematizaçôes que lhes são alheias (a obra de Goethe, particularmente, sofreu mais do que algumas vezes desse mal). A obra de Mazzari, ainda que perpasse, em hercúleo trabalho, os leitores e as leituras a que Fausto foi submetido, náo deixa de permitir que a luz fulcral emane da própria obra em questáo. É a própria tragédia que ganha novas possibilidades com o tratamento de suas leituras que vão desde Hegel e alguns de seus discípulos, como Rosenkranz, até os recentes trabalhos Werner Jägger, passando por Benjamim, Luckács, Paul Celan entre outros. O título da obra remete às tílias que jaziam junto à casinha do casal dos anciães Baucis e Filemon. As mesmas Tílias que, diante dos olhos de Linceu, timoneiro dos argonautas, aqui transformado em atalaia da torre fáustica, são sacrificadas como que em dupla noite no derradeiro momento de sua existência no incên- 
dio da casa dos velhos; uma cena das mais impactantes da tragédia. Colocar esse título, que mostra que o livro centra seus esforços na segunda parte da tragédia, o segundo Fausto, é também uma maneira de se superar uma das maiores injustiças que a tragédia sofreu nos países lusófonos; na excêntrica tradução de Castilho, a mesma que circulou no Brasil na coleçấo Clássicos Jackson, líamos ao final da advertência introdutória a seguinte declaração: "tantos e táo crespos são no último Fausto os enigmas filosóficos, táo abstruso o senso das ficçôes, e as ficçôes mesmas táo desnaturais, tâo inverossímeis, tão impossíveis (ia-me quase escapando táo absurdas) que o bom gosto e o bom senso, que tão benevolentemente perdoaram e receberam a lenda velha do Dr. Fausto, não sei como haveriam com o Fausto último. O primeiro, o nosso, foi um gigante; o segundo figura-se ao espírito da nossa consciência o homúnculo, um produto abusivo das forças da arte."

Mazzari repropóe essa leitura de modo a iluminar exatamente essa segunda parte vituperiada por Castilho, sem ignorar as muitas leituras que foram no mesmo sentido, a começar pela de Rosenkranz, cuja resenha pioneira desse movimento, vaticinava que o Fausto II, "jamais alcançará a popularidade da primeira parte, jamais encantará, do mesmo modo como esta, a naçáo" (p.69). Indo da tragédia do colonizador até a Mater Gloriosa, o livro que aqui se apresenta nos coloca diante dos movimentos desse derradeiro ato (que é segundo o autor do livro "não só um dos pontos culminantes da Weltliteratur, mas também um de seus momentos mais alarmantes" [p. 245]) de modo a mostrar a estética de recepção em pleno funcionamento. Ao repropor a leitura desse complexo quinto ato, retomando de Hans Robert, um precursor dessa Estética de Recepção, "a constatação tomista de que 'tudo que é recebido, é recebido ao modo do receptor'. (p. 213), Mazzari parece também nos inserir entre a obra e os seus leitores. A dupla noite das tílias... é um livro que nos repropóe um jogo "de contrastes e espelhamentos mútuos” (p.205) que se recusa a qualquer reduçáo. Com clara recusa por colocar acima de qualquer outra a "visada cerradamente ontológica ou psicologizante", (p. I4I) que há tanto tempo agardaram os mais diversos leitores de Goethe, Mazzari nos encaminha para uma espécie de terceiro ato da tragédia: suas leituras. Pela fineza com que o texto de Goethe, bem como sua recepção são tratados, podemos dizer que o livro de Mazzari já nasce indispensável por diversas razōes. Talvez a mais importante delas seria a de deixar indicar ao leitor muitas construçóes teóricas em torno do Fausto, mas sem limitar a vida do texto às fontes secundárias; a contraparte desse movimento é a de não sacralizar o Fausto como obra canônica e inamovível. O livro nos convida a nos enfileirarmos com diversos autores canônicos que tentaram desbravar esse emaranhado imagético que é a segunda parte da tragédia de Fausto, mas sem a tentativa de nos trazer uma soluçáo ao texto, pois como diz Goethe, em Carta a Carl F. Reinhardt (a mesma com que Mazzari encerra seu livro), "não espere elucidação; à semelhança da história do mundo e dos homens, o último problema solucionado sempre desvenda um novo problema a ser solucionado." (p. 25I).

\section{Christopher Berry.}

\section{Hume, Smith and the Scottish}

\section{Enlightenment.}

Edinburgh : The University Press, 2018.

\section{Christopher Berry.}

\section{Adam Smith. A very short Introduction. Oxford : The University Press, 2018.}

O chamado "Iluminismo escocês" (Scottish Enlightenment) nunca teve a mesma abundância de referências que as existentes a respeito dos movimentos correlatos na França e na Alemanha. É que os filósofos escoceses modernos se encaixam mal tanto no molde 
da metafísica clássica quanto no de sua crítica, e mesmo Hume, de longe o mais lido, é com frequência diminuído ao papel de um cético que tudo contesta e nada erige pronto a ser superado pela revoluçáo copernicana e seu sucedâneo idealista-romântico. A situaçáo de Adam Smith é ainda pior, pois mesmo, nos países de língua inglesa, onde sua obra é mais conhecida do que alhures, ele tende a ser visto como pai da economia, senáo como fundador do liberalismo (o que quer que se entenda por esta última alcunha). Entre desconhecimento das fontes e preconceito ideológico, as obras de Smith e de seus contemporâneos, com destaque para Adam Ferguson e John Millar, permanecem numa espécie de limbo que náo condiz com a envergadura intelectual desses homens. Contudo, é algo bastante claro, ao menos desde a publicação do estudo de Gladys Bryson (Man and society, 1946), que Hume, Smith, Ferguson e os seus contribuíram de maneira decisiva para a renovação da especulação filosófica moderna, desviando-a dos caminhos tradicionais da metafísica e projetando-a no estudo da sociedade (quer dizer, da política, da economia e da história). Para além de simplificaçóes que veem no conceito de natureza humana um retorno irrefletido do velho sujeito metafísico, ou na ordem espontânea das relaçóes econômicas um ardil teológico, ou ainda, na crítica do finalismo um capítulo infeliz no estudo dos seres vivos, os escoceses vêm nos mostrar coisas novas a respeito dessas questóes, mas que nem sempre são do agrado da filosofia mais tradicional. Concedamos a Foucault o mérito que lhe cabe por ter alertado seus ouvintes, em sucessivos cursos ministrados no Collège de France na segunda metade da década de 1970, para a relevância dos escoceses para o pensamento contemporâneo, ao mesmo tempo em que apontava para a presença, entre eles e nós, de descontinuidades suficientemente profundas para que náo nos enganemos quanto a uma suposta responsabilidade desses pensadores céticos ou cautelosos por desmandos ideológicos muito posteriores a eles.
$\mathrm{O}$ inglês Christopher Berry, professor aposentado de teoria política na Universidade de Glasgow, não padece dos pecados que poderiam ser imputados às leituras ligeiras da tradição escocesa. Ao contrário, vem contribuindo, de forma decisiva, com uma série de estudos, que culminam, por ora, nos livros em resenha, para uma compreensão ampla, profunda e nuançada do pensamento político-econômico de Hume, Ferguson Smith e outros. Insere-se assim em uma linhagem que remonta a Duncan Forbes (Hume's Philosophical Politics, 1975), estranha às generalizações dos neorrepublicanos alocados da escola de Pocock e Skinner, e que concede aos inventores da economia política (ou de uma vertente dela) um quinhăo bem maior do que o de ter renovado, aqui e ali, a teoria política oriunda de Maquiavel, Hobbes ou Espinosa. Os artigos de Berry reunidos em Hume, Smith and The Scottish Enlightenment oferecem uma perspectiva variada acerca de diversos tópicos relativos à indicação do título, mas preservam sempre o mesmo diapasáo: a ideia de fundo, que vibra na especulação escocesa, de "aprimoramento" (improvement), ideia sutil e nuançada, marcada por um pessimismo mitigado, segundo a qual as formas de organização política, quando amparadas em uma aplicação regular e constante de princípios jurídicos claramente estabelecidos, propiciam, até certo ponto, e dadas circunstâncias favoráveis, o desenvolvimento de propensōes inscritas na natureza humana - alcunha tomada, pelos autores em questão, como conjunto das características especificas, isto é, determinadas fisiologicamente, do animal a que se refere. Atento às importantes divergências doutrinais entre os escoceses, Berry destaca as singularidades de cada um deles, mostrando que elas são muitas e interessantes, sem, no entanto, perder de vista o horizonte comum de suas preocupaçóes. Nesse sentido, o livrinho sobre Smith, embora seja uma introduçáo, traz uma contribuição importante, ao pôr em relevo o caráter sistemático da obra desse autor, que organizou sua própria filosofia de acordo com os 
princípios da análise encontrados na ciência (com destaque para a física em sua aplicação à astronomia) e na linguagem (a gramática geral em sua versão renovada pelos enciclopedistas). Berry retoma assim, por conta própria, e com clareza exemplar, um fio de uma trama tecida por Andrew Skinner em $A$ system of social Science, 1979; $2^{\mathrm{a}}$ ed. 1996), se não me engano a primeira obra a mostrar em detalhe a coesão das travaçôes conceituais que póem de pé o edifício da filosofia de Adam Smith.

\section{Daniel Diatkine.}

\section{Adam Smith. La découverte du capitalisme et de ses limites.} Paris: Seuil, 2019.

\section{Claude Gautier. Voir et connaître. Regarder à distance dans les Lumières écossaises.} Lyon: ENS, 2020.

A pequena literatura filosófica sobre Adam Smith em língua francesa recebeu recentemente duas contribuiçóes de relevo. O livro de Daniel Diatkine é importante pela simples razáo de mostrar, com apoio nos textos de Smith, que a sociedade e os modos de relação políticos e comerciais descritos na Riqueza das naçôes, não constituem motivos de uma apologia, mas são vistos pelo filósofo escocês como objetos de investigaçáo precisa e minuciosa, à qual cabe, acima de tudo, determinar a natureza bem como os limites da chamada "sociedade comercial". A esse termo um pouco recatado Diatkine prefere a expressão "capitalismo", por certo anacrônica, pois não se encontra em Smith, nem é utilizada na época, porém acertada, na medida em que a obra de Smith pode e deve ser lida como a problematização de um mundo que, na segunda metade do século XVIII, vai ganhando contornos que se tornarão mais nítidos no período subsequente, mas cujo elemento fundamental foi identificado na Riqueza das naçôes
- o trabalho como fonte e origem da riqueza. Trata-se, com isso, de acertar as contas com variadas apropriaçóes de Smith que, de Hegel a Marx, por um lado, e de Ricardo e aos marginalistas, por outro, insistem em apontar para as supostas limitaçóes de sua teoria como fundamento da ciência econômica, como se ela devesse, bizarramente, dar conta de anseios que excedem os objetivos a que ela se propóe (lembrando que economia política se inscreve, para Smith, no ramo da jurisprudência, que, por sua vez, é uma ramificação do tronco mais espesso da filosofia moral). Smith era, tal como seu amigo Hume, um newtoniano resoluto, um filósofo amigo da ciência experimental, cioso de manter toda teoria restrita ao plano da identificaçáo de relaçóes de causa e efeito, despreocupado com princípios últimos e fundamentos definitivos. Em consonância com isso, um dos melhores momentos da análise de Diatkine é aquele em que ele mostra (no cap. 3), com base em uma passagem da Teoria dos sentimentos morais, que a convergência inaudita de interesses contraditórios que marca o equilíbrio espontâneo e dinâmico do sistema comercial ou capitalista não advém, de modo algum, de uma combinação entre paixóes contraditórias, mas, isto sim, da submissão destas, em cada indivíduo, a uma perspectiva sistemática tal que lhes confere um caráter geral — de signo - que, de outro modo, lhes faltaria. A economia de Smith é uma ciência gramatical: se o homem é o único animal que troca porque é o único que fala, e é, portanto, o único que toma uma sensação como signo de outra, estendendo assim o seu valor, cabe ao filósofo identificar a lógica dessas extensóes valorativas e dos domínios de significaçâo correlatos a elas. Daí o lugar de relevo, no sistema filosófico, de Smith, da ideia de instinto, apontado por Diatkine, mas que ainda resta por ser determinado com mais precisão.

O livro de Claude Gautier opera em outro registro. Voltado para as "Luzes escocesas" referidas no título, é, na verdade, uma longa, conturbada e não raro obscura, medi- 
tação sobre a constituição de um "olhar distanciado" como condiçáo de possibilidade do programa sociológico delineado pelos escoceses. Gautier estuda Hume e Smith; dedica poucas páginas a Ferguson, e não menciona Robertson nem Millar, o que náo deixa de causar certa estranheza ou decepção, pois é na obra destes que se encontra algo efetivamente mais próximo, entre os escoceses, de um estudo sociológico dos modos humanos de organização política. Embora dedique páginas a Descartes e a Leibniz, Gautier não menciona Rousseau, o mestre, senão do distanciamento, ao menos do estranhamento como maneira de apreciação da sociedade política. Feitos esses reparos, é preciso reconhecer que o livro é meticuloso, e que a atenção do autor aos textos produz acertos preciosos em diversos momentos da análise, como aliás ocorre também em outros trabalhos de Gautier. É o caso, principalmente, de todo o capítulo 4, cuja primeira metade é dedicada à questão intratável — da teleologia na obra de Smith. Percorrendo um terreno pisado não somente por Diatkine, como também por outros excelentes estudos precedentes, como os de Christian Marouby (L'Économie de la nature, 2004) e de Michel Biziou (Adam Smith philosophe, 1999), Gautier vai além deles. Começa por determinar o engendramento de um ponto de vista teleológico para explicar as açôes morais na Teoria dos Sentimentos Morais (I759), e mostra, em seguida, como o ensaio sobre a História da Astronomia (I795; póstumo) vem relativizar essa perspectiva. Tendo flertado com o providencialismo, o próprio Smith introduziria uma cisão, entendendo que os fins da imaginação, concomitantes a tendências naturais, não devem ser tomados por fins naturais, por uma orientação teleológica. Cabe concluir, a partir da sugestiva análise de Gautier, que, se o Deus de Kant é um produto da razão em seu uso prático, a finalidade de Smith é uma simples ilusão, interessante e quiçá necessária, que a filosofia vem identificar enquanto tal, e à qual, uma vez feito isso, concede alguma legitimidade. Di- ferentemente de Hume, que, nos Diálogos sobre religiáo natural (I779), recusa à teleologia todo estatuto conceitual, Smith entende que é preciso perpassá-la para determinar assim, ao certo, a sua origem. Menos a arqueologia de uma ilusão do que a gênese de uma ficção, a discussão de Smith a respeito é, como mostra Gautier, nada menos que extraordinária.

Jonathan Rée.

Witcraft. The Invention of Philosophy in English. Londres: Allan Lane/Penguin, 2019. $746 \mathrm{pp}$.

Uma coisa é escrever uma história da filosofia inglesa ou da filosofia de língua inglesa; outra, bem diferente, é escrever uma história que é também uma investigação, uma busca pelo gênio característico da filosofia escrita e lida em língua inglesa através dos tempos. O livro de Jonathan Rée ignora procedimentos canônicos tradicionais. Em vão busca-se em suas páginas pela reconstituição das honoráveis linhagens do empirismo, do utilitarismo e da filosofia analítica, que teriam marcado a tradição dita "anglo-saxônica" por contraposição à filosofia “continental”. Rée não tem tempo para essas distinçóes postiças e paroquiais, e começa com uma seção intitulada "I6or. Philosophy learns English", aprendizado que, como ele mostra, implica o abandono progressivo do latim. No período imediatamente posterior (examinado na segunda seção, "I65I. Puritans, Philosophers, Comedians"), entra em cena a filosofia francesa e o profundo impacto das doutrinas de Descartes e Malebranche na Inglaterra de Bacon e Hobbes. Já na terceira seção ("I7or. Politics, Religion and the two new Philosophies"), somos apresentados ao controverso John Toland, filósofo irlandês "deísta", discípulo de Locke, mas que muitos consideravam simplesmente um ateu, pecha que, como se sabe, desde o Dictionnaire Philosophique de Bayle recaía sobre todo aquele que ousava mencionar Espinosa sem de imediato intro- 
duzir uma censura a suas doutrinas. Nos capítulos subsequentes, encontraremos escoceses (Hume, Smith), norte-americanos (Emerson, James), e um austríaco, com o qual Rée encerra sua narrativa: Wittgenstein. A seção "I95I. A Collection of Nonsense" é um desfecho brilhante, pois, além de a escolha ser pertinente - é defensável que Wittgenstein tenha sido o maior filósofo anglo-saxão do século XX —, Rée não tem tempo para o exercício de glorificaçáo de seu personagem, mantendo-se distante das seitas de seus seguidores dogmáticos e desinteressantes.

O caráter idiossincrático de Witcraft é explícito desde o trocadilho de sabor swiftiano do título. A expressão wit, que pode ser traduzida por engenho, por espírito, ou mesmo por gênio, é glosada por Rée na segunda parte do título, com a escolha certeira do termo "invenção", que, em sentido duplo - retórico, romântico - diz o ato de encontrar algo pertinente à ocasiáo junto a um repertório dado previamente, mas também o de criar algo que novo e original. Não são atos excludentes, e, na hábil montagem do livro, fica claro que filosofar em língua inglesa é colher lugares-comuns junto a uma tradição que, no entanto, se renova constantemente nesse processo e que termina por se firmar, no pósguerra, junto às tradiçóes francesa e alemá, como hegemônica em escala global. Não se trata com isso, evidentemente, de insinuar uma superioridade congênita qualquer, que teria levado a filosofia de língua inglesa da periferia ao centro do mundo intelectual, mas, antes, de destacar o caráter histórico desse processo e de apontar para as conexóes entre os filósofos que escreveram em inglês e aqueles que se exprimiram em outras línguas. Vai no mesmo sentido o esforço, em meu entender exitoso, de ampliar a concepção disso que se chama de "filosofia", o que permite a Rée, por exemplo, dar destaque à figura do ensaísta e crítico inglês William Hazlitt, ou de seu contemporâneo, o poeta e crítico Samuel Taylor Coleridge, que, de fato, cabem, pela envergadura intelectual, em uma história como essa. Outro acerto é o relevo conferido às mulheres, cuja importância na filosofia de língua inglesa é amplamente discutida por Rée, que tem páginas de interesse não apenas sobre Mary Woolestonecraft, mas também sobre George Eliot. Dada a perspectiva aberta e variada a partir da qual Rée constrói sua narrativa, fica uma decepção de não terem mais destaque outros nomes como Jane Austen ou Virginia Woolf. Mas podemos imaginar o tratamento que elas teriam recebido, caso esta história fosse se tornar ainda mais detalhada.

\section{Laurent Jaffro. \\ La couleur du goût. Psychologie et esthétique au siècle de Hume. Paris: Vrin, 2019.}

A primeira coisa que chama a atenção no mais recente livro de Laurent Jaffro é o título. À primeira vista convencional, estruturado segundo as regras acadêmicas — uma frase geral seguida de uma cláusula subordinada explicativa - , ele contém uma dupla ousadia. É rara a associação proposta entre o sentido da visão e o do paladar, como se o sabor dos alimentos tivesse uma gama, composta por diversas tonalidades; mais rara ainda é a ideia de que essa associação tenha algo a dizer sobre o gosto enquanto sentimento de prazer e desprazer aplicado às produçôes da arte. $\mathrm{Na}$ filosofia da primeira metade do século i8 encontra-se uma hierarquia entre os sentidos, a visão ocupando o topo, aproximando-se do intelecto - como no uso das formas geométricas —, o tato o lugar mais baixo, ligado à sensação puramente fisiológica. Mas a hierarquia entre os sentidos espelha aquela entre o espírito e a matéria, a alma e o corpo. É sabido que Diderot subverteu essa ordem de maneira decisiva, na Carta sobre os cegos para $o$ uso dos que veem (1749), consignando ao tato a primazia na produção das representaçóes mais abstratas e relegando a visão quase à condição de um sentido ilusório. O Tratado sobre as sensaçóes de Condillac (1754) explora essa mesma via, colhendo resultados algo diferentes daqueles de Diderot. Mas o livro de 
Jaffro é sobre o século de Hume, não de Diderot ou de Condillac. Daí a força do subtítulo, que explica que o objeto do estudo são as relações entre a psicologia (da percepção) e o gosto (do prazer e desprazer) em uma época dominada, ao menos em parte, pela força das injunçôes estabelecidas por Hume no Tratado da natureza humana (174I) e em diversos ensaios, com destaque para $O$ cético (I74I) e Do padráo do gosto (I758).

Marcado por um fino senso de análise, o livro é também inteligente, como se vê no modo como é organizado. Evitando o ridículo de tomar o partido de Hume, e indo contra, portanto, toda uma inclinação de nossos tempos, em que filósofos são tomados como chefes de escola ou bandeiras ideológicas, Jaffro recua e ganha força ao mensurar o impacto de Hume não na "epistemologia" ou na "estética" de sua época, mas no modo de pensar ilustrado, no qual a constituiçáo da própria racionalidade é pensada como um processo sensível. De um só golpe, vemos a obra de Hume ser subtraída à pobre denominação de empirismo, ao abrigo da investida kantiana, indiferente à apropriaçáo rasa da fenomenologia, restituída em sua originalidade e também, o que não é pouco, ao nosso tempo. De súbito, a teoria da percepçáo deixa de ser uma anomalia, o índice de uma patologia do outrora sadio racionalismo, para se tornar a regra. Em seu percurso, que passa por numerosos autores do século humiano, Jaffro se concentra na Inglaterra e na Escócia. Seus pontos de ancoragem não são os "grandes autores" canonizados pela filosofia universitária, mas filósofos hoje um pouco esquecidos, que têm, no entanto, de ser recuperados, se quisermos apagar, de uma vez por todas, a imagem de um período da modernidade excessivamente maculado por projeçóes retrospectivas, e reencontrar o potencial crítico que ele guarda para a nossa própria reflexão. Um bom exemplo é capítulo 3, "A via da técnica", dedicado ao filósofo inglês James Harris (1709-1780), em que Jaffro destaca a reviravolta na concepçáo de atividade técnica na pena desse escritor, que, embora divirja, com seu aristotelismo, em relação a Hume, permite compreender passagens mais obscuras dos argumentos de Filo contra a teleologia nos Diálogos sobre a religiāo natural, e, o que não é pouco, relativizam o alcance e a originalidade de certas consideraçôes de Kant na Crítica do Juizo (1790). O efeito é enviar-nos diretamente às páginas de Harris, pronto para ser redescoberto como filósofo de fôlego. Com isso, mal começamos a dar uma ideia de um livro notável, em que a história da filosofia é aliada a uma perspectiva analítica contemporânea. Combinação bem francesa, que produz resultados estimulantes. 


\section{Fora da Estante}

\section{Rubens Rodrigues Torres Filho. 0 espirito e a letra. A crítica da imaginação pura, em Fichte. São Paulo: Editora Ática, 1975.}

Publicado em 1975 e jamais reeditado, $O$ espirito e a letra. A crítica da imaginação pura, em Fichte, livro de Rubens Rodrigues Torres Filho, pode ser considerado como um marco tanto nos estudos brasileiros de filosofia alemâ, que ajudou a consolidar, quanto na trajetória da "escola paulista de filosofia" (expressão recentemente cunhada na França). Aparentemente, o estudo é um simples exercício da hoje tão deplorada "explicação de texto”. Mas, como elucida a apresentação, o método de explicação de texto - bem entendido, estrutural - está vinculado, para o interessado em Fichte, a uma compreensáo da peculiaridade dessa filosofia, que, em alguma medida, impóe restriçóes sérias a toda tentativa de ir além de "interpretar Fichte pelo interior” (p. I2). Ainda nas palavras de Rubens, "procurei apenas pôr em evidência a economia interna do sistema, suas articulaçóes e sua coerência, esperando fazer dessa limitação uma vantagem, graças ao auxílio de um único fio condutor, que me pareceu privilegiado: o papel da imaginação" (p. I2). O leitor de 2020, desavisado e talvez pouco afeito à fineza de uma ironia discreta, mas náo menos cortante, faria bem em dar ao "apenas" aí grafado todo o peso que ele tem, pois, como ficará claro dos quatro vertiginosos capítulos, e da conclusão, a "mera" explicação de texto é elevada, por Rubens, no caso de Fichte, a um exercício especulativo de primeira ordem, em que a decifração do original, lido em alemáo e traduzido no calor da hora e com exímia precisão, é acompanhada de vigorosa reflexão conceitual, sem o que, no entender de Rubens, o intérprete não seria capaz de acompanhar a especulaçáo de Fichte — que exige de seu leitor o mesmo empenho que ele próprio, o autor, teve de fazer para elaborar um sistema que costuma ser considerado entre os mais difíceis da história da filosofia. Mas não se trata com isso de mimetizar Fichte. Daí a escolha de um "fio condutor" (o Leitfaden, que o filósofo alemão encontrou junto a Kant), que "parece' a Rubens adequado para levar a cabo a reconstrução, com força própria, das travaçóes desse edifício especulativo singular. Seria o suficiente para desfazer o mal-entendido que confunde a explicação de texto, nesses termos, com o fichamento e seus derivados. Mas O espirito e a letra não para por aí. Aduz, desde a referida apresentação, apontamentos no sentido de mostrar a formulação, por Fichte, de conceitos que depois se tornam moeda corrente na filosofia: "por exemplo, a alienação e a transferência, constituídas por determinação recíproca a partir da imaginação transcendental", como se Marx e Freud se tornassem, de súbito, interdependentes (p. I2). Igualmente, mas agora em sentido retroativo, a descoberta fichtiana da imaginação transcendental "significará, antes de tudo, que se trata aqui da faculdade instauradora da própria atitude transcendental" (p. 19), que, como se sabe, foi inaugurada por Kant. Rubens não hesita, alhures, em fazer apontamentos similares em relação ao Estruturalismo (então em voga no Brasil e no mundo) e a Wittgenstein (já então à espreita nos meios da filosofia paulista). Anos mais tarde, no ensaio "Produção extrateórica da síntese" (1992; ressurgido na $2^{\mathrm{a}}$ edição de Ensaios de Filosofia Ilustrada), a minuciosa reconstituição de um argumento das Cartas filosóficas de Schelling o levará a reconhecer aí a certidáo transcendental de nascença da dialética hegeliana. São conclusões inesperadas, a que a história da filosofia pode levar, sobretudo quando praticada com o rigor e a precisão que sempre foram característicos desse mestre. 